\title{
Conceptual Change among Arab Student Teachers
}

\author{
Ruwaida Abu Rass ${ }^{1}$ \\ ${ }^{1}$ The Academic Arab Institute for Education at Beit Berl College, Kfar Sava, Israel \\ Correspondence: Ruwaida Abu Rass, The Academic Arab Institute for Education at Beit Berl College, Kfar Sava, \\ Israel. Tel: 972-9-878-3526. E-mail: aburass@beitberl.ac.il
}

Received: September 14, 2012

doi:10.5539/jel.v2n1p189
Accepted: December 25, $2012 \quad$ Online Published: February 22, 2013

URL: http://dx.doi.org/10.5539/jel.v2n1p189

\begin{abstract}
This paper reports the results of a qualitative research study designed to examine the effectiveness of an attempt to make a conceptual change among pre-service teachers to their role as trainees and the role of their pedagogical advisor. The participants are six Arab-Muslim female student teachers who are highly influenced by their first learning experiences, based on rote learning and memorization. Therefore, they tend to prefer ready-made approaches to risk taking, trial and error and enquiry manifested by employing different teaching methods, ideas and techniques. They also tend to prefer authority controlling relationships rather than perceiving learning and teaching as a long-life process. The results indicate some improvement in their inclination to depend on the pedagogical advisor and their willingness to try different methods of teaching, activities and techniques, making mistakes and learning from them. However, more time and ample opportunities for practice are needed to achieve the desired change.
\end{abstract}

Keywords: conceptual change, student teachers, pedagogical advisors, varying methods

\section{Introduction}

\subsection{Introducing the Problem}

Teacher educators are often viewed as authorities who prescribe what student teachers do; if so, it follows that student teachers should listen, accept, occasionally express an opinion, but finally follow a prescription (Gebbard, Gaitan, \& Oprandy, 1990). In modern societies, the roles of teacher educators as well as student teachers have changed because learning and teaching become a life-long process of trial, error, and inquiry rather than an end by itself (Jarvis, 2006). The student teacher is seen as a thinker and the teacher educator as an advisor. In addition, current thinking on English as a Foreign Language instruction (EFL) encourages student teachers to employ a variety of approaches, strategies, and techniques (Richards \& Farrell, 2011). Therefore, the desired change is for the students to view the advisor as the person who helps them acquire skills, styles, and codes of behavior in order to be more autonomous in their profession, and not as one whose sole purpose is to prescribe, supervise and evaluate their lessons. If this perception is internalized, trainees will be encouraged to think about their performance, to vary their methods and ways of teaching and develop their autonomy for professional development.

Little research has been conducted concerning the roles that assumptions and beliefs play in decision making among pre-service EFL teachers' roles in general (Richards, 1998), and for this population in specific. Conducting this study was important for me as a teacher educator and an agent for change who worked constantly and systematically to provide my students with emotional as well as professional help and support through providing multiple opportunities to practice teaching in order to promote their autonomy and to empower them. This mission was not easy. Overall, challenging existing beliefs, considering other alternative models or perspectives and reconstructing ideas and beliefs are all fraught with difficulties (Hill, 2004). This is epecially true for my student teachers who are highly influenced by previous learning experiences which are characterized by transmission of material, memorization, and rote learning (Abu Rass, 2011; Al-Haj, 1996). In addition, Arab teachers tend to be authoritative and do not encourage "expressions of opinions, criticisms, liberal attitudes, or arguments" (Eilam, 2002, p. 1660). Therefore, my student teachers prefer ready-made recipes for delivering lessons rather than experiencing a wide range of ideas, activities, techniques, and strategies.

The present study emerged from the need to make a conceptual change among Arab student teachers who tend to prefer ready-made approaches to risk taking, trial and error and enquiry. They also tend to prefer authority 
controlling relationships rather than perceiving learning and teaching as a long-life process, which is also one of the concepts of EFL methodology in the contemporary world. Therefore, an attempt was made to support this population in specific to change their perception of their roles as receptive student teachers to be more independent thinkers and reflectors in order to be well-qualified teachers in the $21^{\text {st }}$ century who will be able to analyze their performance, evaluate their lessons objectively, be aware of their strengths and weaknesses and find alternatives to improve their performance. By carrying out this attempt, they were also expected to perceive my role as an advisor rather than a prescriber who dictates and gives orders to students. The aim of making such an attempt is to qualify EFL Arab teachers not only to teach English effectively, but also to promote their autonomy and to empower them. In addition, when teachers control the process of learning of their pupils, they limit their potential and ignore their needs. The research question was aimed to examine the effectiveness of such an attempt. Thus, the question was: What effect does this attempt have on the student teachers' perception to their roles and the role of their pedagogical advisor?

\subsection{Theoretical Background}

Teachers' beliefs are often composed of concepts, perceptions, perspectives, and opinions that are usually affected by their prior learning experiences (Pajares, 1992). Conceptual change is the transformation that takes place in an individual's ideas, thoughts, and approaches as a result of experience. Shaping one's beliefs is not easy, and even a challenging mission (Hill, 2004).

For many years control-oriented schooling which is based on prescribing rather than advising or providing opportunities for practice was widely implemented (Kegan, 1994). This approach means that the teacher educator controls the process of student teachers' learning and decides the steps for them. It is important to qualify long-life teachers who can develop professionally and think independently because "learning to teach is a long-term complex developmental process that operates through participation in social practices and contexts associated with learning and teaching" (Freeman \& Johnson, 1998, p. 402). This statement emphasizes the need of adopting a constructivist view of teaching which considers language teaching as a process of knowledge construction rather than a process of knowledge transmission.

Autonomy-supportive education is constructive and developmental in nature, which encourages providing ample opportunities for practice, inquiry and reflection and challenging students to take responsibilities for making decisions and choices (Kegan, 1994; Perry, 1999). According to Hill (2004), "the intention of inquiry is to formulate tentative judgements open to further inquiry and development, rather than closed and complete judegements" (p. 33). Therefore, teacher learning must include the processes of exploration, interpretation, and negotiation to help pre-service teachers investigate the sources of their knowledge and beliefs (Mori, 2003). Supervising and evaluation of teacher learning should be nonjugemental to encourage student teachers take risks (Gebhard \& Oprandy, 1999).

To help pre-service teachers construct knowledge and develop as long-life learners, the pedagogical advisor is expected to support the student teachers in three aspects: socio-psychological, professional and reflective (Emmanuel (2005). The first aspect refers to the need for providing emotional support to help the trainees cope with the shocking reality of the teaching profession and to alleviate the personal pressure that accompanies the practicum (Wang \& Odell, 2002). Thus, pedagogical advisors are expected to create a supportive environment and show caring attitudes toward their student teachers to support them emotionally and personally as individuals and a group. For example, if a student teacher has a bad experience in her teaching, the pedagogical advisor should support him/her emotionally by explaining that negative experiences are part of the reality of teaching in schools. The advisor should help the student overcome his/her bad feelings and to think rationally about what happened and how it could be repaired.

The professional aspect refers to knowledge and skills that student teachers develop throughout their studies (Emmanuel, 2005). According to (Zilberstein, 2003), pedagogical advisors are expected to acquaint the trainees with professional standards, among them the main concepts of teaching a specific subject matter, deliver the subject matter to pupils and expose them to ways pupils learn and to social and intellectual factors that affect learning. It means focusing on acquainting the trainees with practical knowledge and the social culture of the school (Resnick, 1987). In addition to acquainting them with the hetrogeneous reality of the classrooms, advisors should introduce different learning styles and strategies and guide them to match their teaching style with the learners' styles. The aim is to provide the student teachers with a solid knowledge of the subject matter and with the tools to develop a positive environment for learning (Zilberstein, 2003). Advisors should also expose the trainees to alternative ways of instruction (Zahorik, 1988). The focus is on a descriptive set of alternatives in terms of activities and opportunities of learning in order to enable pre-service teachers to initiate, explore, 
examine and interpret their own teaching and become reflective teachers (Farrell, 2004; Gebhard, 1992: Murphy, 2001).

The third aspect refers to developing the trainees' abilities to reflect and to evaluate themselves and their pupils (Emmanuel, 2005). Reflecting means thinking about actions with a view to their importance, evaluating them, and seeking possible solutions or alternatives (Ferraro, 2000). Pedagogical advisors are expected, first, to help the trainees develop skills for evaluating pupils' work, progress and achievement (Zahorik, 1988). Second, advisors should provide reflective feedback on the trainees progress' and professional development as they qualify them for teaching. Third, advisors are expected to help the trainees develop their reflective skills for self-evaluation of their progress. Later, the pedagogical advisors are expected to be agents for change, helping the trainees develop critical thinking towards their knowledge and pedagogy (Cochran-Smith \& Lytle, 1999).

Some studies have been conducted to examine the impact of teacher education programs that were designed to make conceptual change to develop students' professional growth and development. For example, Hill (2004) investigated the usefulness of the Development Education for Conceptual Change Program (DECC) which emphasized promoting student teachers' intellectural development through dealing with pedagogical complexity and reflective thinking following the autonomy-supportive education and the community of inquiry approach to teaching. Students were encouraged to ask questions, voice their opinions, take risks and support each other. Findings suggest that participating in the DECC program made a modest contribution to the students' intellectual growth and to their willingness to employ more autonomy-supportive pedagogical approaches.

Another study was conducted by Tillema (1997) to examine the promotion of conceptual change in learning to teach. Course materials were developed and conceptual change among student teachers was embedded in them. A pre-post teaching-belief test was employed to detect specific beliefs about the orientation to teaching and learning whether it is more controlled and directed or self-regulated. A total of 63 student teachers divided into three groups participated in the program. The results showed that the performance of these student teachers did change, but their beliefs did not.

In order to make the desired internal change in perceptions of teaching in current language teacher programs, the pedagogical advisor acts as a mediator who tries to make cognitive as well as personality changes in the trainees through repeated interactions. To achieve this goal, the supervision role of the teacher educator must be abandoned and replaced to provide support and opportunities for practice (Jarvis, 2006; Richards \& Farrell, 2011). To do so, teacher educators must hold frequent meetings with the students, which should be devoted to analyzing situations, and through this intense analysis students are encouraged to develop and grow personally and professionally. An important component of this ability to grow is an ongoing review of their performance to help them reveal aspects of their teaching that they are not aware of and provide a basis for discussion (Richards \& Farrell, 2011).

In the second-language teaching literature, theorists present a contemporary perspective by recommending a variety of approaches, strategies, and techniques to teach the language effectively and help learners learn successfully (Richards \& Farrell, 2011). Language Teacher Education (LTE) programs must encourage and support the students to risk taking experiencing alternative models (Farr, 2010). Developing teacher expertise is an on-going process that cannot be achieved in year-long LTE programs (Farr, 2010). In addition, observation of different kinds of second-language classess is very essential to student teachers. Such observations could orient the student teachers to the nature of the second-languague classroom in terms of organization, practices, and norms that enable student teachers develop an awaress of the kinds and levels of possible classroom interaction (Richards, 1998).

The EFL pedagogical advisors' mission is demanding as they must be fully competent not only in the target language, but also in foreign language pedagogy (Farr, 2010). These advisors should help their student teachers develop their communicative competence and performance of the target language and the methdology for teaching it effectively. However, the focus of this research is only on promoting pedagogic competence to pre-service teachers as long-life learners.

\section{Method}

\subsection{The Attempt}

Following the contemporary approach of EFL, an attempt was made to challenge the student teachers' beliefs about their roles as receptive to long-life learners and my role as an advisor rather than a prescriber. Instead of transmitting material and giving them orders, I did my best to foster independence in thinking and performing through encouraging trial and error in classroom applications. I also took a nonjudgmental stance through 
supervison by encouraging them to employ different teaching methods, ideas and techniques, and reflect on their performing experiences to empower their exploration through multiple-activities.

To do the desired change, my student teachers were encouraged to critically analyze their field notes, evaluate their performance and provide oral and written self-reflections in order to have valuable insight and direct evidences to their performances. In addition, the feedback sessions were held not to provide evaluation, but to promote their independant thinking and decision making. Following the discussion of Emmauel (2005), emotional, professional as well as reflective feedback was provided in a supportive environment in the weekly feedback sessions.

In these sessions, the students, in turn, were invited to report about their own lessons and listen to the feedback of their peers who observed them and answered guiding questions presented to the students after their lessons, which aimed to promote self-awareness and self-discovery of who they were as teachers in the lessons they taught. They did not take the form of criticism but rather attempted to promote reflective thinking about their teaching. The pertinent guiding questions were about the variety of the activities, their reception by the pupils, their timing and effectiveness in terms of the learning content, the management strategies used during the lesson, the pacing of the instruction, occasional problems with technology, and suggestions for improvement. The aim was to help student teachers go beyond simple evaluative words and stimulate analytical and critical reflection and self-evaluation.

Moreover, the participants were discouraged from the use of guidebooks, which are offered by the publishing companies and include very descriptive detailed steps for teaching the lessons.

\subsection{Participants}

The participants in this study were six third-year female Arab students, who majored in a four-year program for teaching EFL at a teacher education college in central Israel.The program covers three areas: language competence and performance, language pedagogy, and teacher education. The participants practiced teaching at a junior high school in an Arab town in the centre of Israel attending the school for five hours. Each taught one lesson a day, and I accompanied them in my capacity as a pedagogical advisor. In addition, they practiced teaching intensively for five days a week twice throughout the school year. They also attended an advanced course in EFL pedagogy at the college which was designed to familiarize them with current pedagogy as well as methods of teaching ESL/EFL in junior high schools. To preserve anonymity, the participants chose pseudonyms: Daboul, Nola, Zuzu, Dobi, Salim, and Cool. To guarantee objective evaluation to my attempt and its effects on making conceptual change, two neutral experienced pedagogical advisors were invited to accompany me throughout the school year. The first visit was carried out in the first intensive practical work week, and the other visit was held during the second one.

\subsection{Measures}

Data sources are: (1) a portfolio which included the following: (a) the lesson plan sheets, (b) the three evaluations, (c) the observation notes of the student teachers, (2) my observation notes and notes that documented the discussions during the feedback sessions, (3) two questionnaires and 4) interviews.

Pre-post questionnaires were developed to examine changes in perceptions, beliefs, knowledge, and performance. They included questions about their experience of practice teaching including their expectations from their pedagogical advisors. To guarantee objectivity, the questionnaires were collected and kept in an envelope, which was put aside. They were accessed at the end of the school year after I submitted the participants' grades of the practicum.

In-depth interviews are usually used in qualitative research to assess the degree and nature of professional growth (Kegan, 1992). Here, the formal interviews sought to elicit their reactions and thoughts about the way of advising, providing help and support, and their personal transformation and conceptual change.

\subsection{Research Design}

The six student teachers were required to teach a lesson every week, observe two, fill in observation sheets, and participate in the feedback sessions. To practice teaching, the student teachers filled in a lesson plan sheet, which required them to describe their steps, prepare an extra task to help them survive in cases of emergency, evaluate the effectiveness of the activities employed in the lesson and reflect on them mentioning what activities should be used or should not be used in future lessons and why.

Participation in the weekly feedback sessions was mandatory. These sessions - attended by the student teachers, the English teachers in the school, and the pedagogical advisor - were called to discuss the students' preparation 
and practice. In addition, the participants were expected to indicate any change they have witnessed in their preparation and performance.

\section{Results}

For this research, qualitative data derived from the above-mentioned sources were systematically organized, coded, and indexed. For example, repeated data about beliefs and changes obtained from interviews, field notes, feedback sessions and the two questionnaires were grouped together for interpretive analysis.

In addition, the gathered field notes that included class observations and staff meetings were chronologically and thematically analyzed. Data analysis included the following categories: a) expectations from the pedagogical advisor, b) employing different strategies and techniques to include teaching through songs, stories, games, etc.; (c) exposure to different settings.

Over all, data analysis revealed differences among the student teachers in their expectations from the pedagogical advisor, the ability to employ a variety of methods and activities and to adopt to different settings. While Daboul and Nola were ranked first, Dobi and Zuzu were ranked second. Salim and Cool were grouped together and ranked third due to their little improvement in the three above mentioned categories.

\subsection{Expectations from the Pedagogical Advisor}

The participants' expectations from their pedagogical advisor mentioned in their answers in the first questionnaire were very high. The following paragraph is quoted from Daboul's final evaluation to her experience as a trainee, which shows the little change in her perception to teaching. As a result of this change, she started to think about her practice and performance in a different way.

To summarize the experience I had this year I would thank my pedagogical advisor who helped me gain new ideas and think about things in a different way, although I didn't always like it, but I can't deny her help for me, also the support she gave for all of us. Also, I would like to thank my classmates who helped me with their ideas and support in many times.

While four students, Nola; Zuzu; Salim and Cool, expected me to tell them exactly what to do, only Daboul and Dobi didn't. By the end of the school year, little change has been witnessed in their expectations. Nola, Salim and Zuzu still expected the pedagogical advisor to dictate things for them while the rest didn't think that way. Similarly, all of them expected the pedagogical advisor to control their performance by telling them exactly which steps should be taken. However, only Daboul, Salim and Zuzu continued having the same expectations in the second questionnaire. The most obvious change was reported regarding lesson planning. While Daboul and Dobi expected little help, the rest thought of having much help at the beginning of the school year. In contrast, all of them had the same expectations at the end of the school year.

The extreme change is demonstrated by Nola and Zuzu who expected very much help at the outset and very little at the end. The participants' answers for the expected help regarding the choice of the most important activities showed some change in their expectations too. While four, Daboul, Zuzu, Salim and Cool, expressed their desire of being helped to choose the appropriate activities at the outset, only Cool did that at the end. Only Dobi expected little help at first, four reached that conclusion at the end. These results are in line with their answers in the interviews mentioning the words "support", "advise" and "help" to describe the role of the advisor and indicated that the student teachers were more dependent at the beginning of the school year than at the end. For example, Cool commented in her final evaluation on the transformation she passed through by the following:

I learned a lot about myself, for example, at first even when the practical work week ended I was in denial- I did not accept criticism, and thought myself as the best teacher! But I wasn't. I'm learning gradually.

Although some of the answers indicate some shift in their perception to the role of the pedagogical advisor, still, this shift is in not significant. These results correlate with the observation notes which indicated the student teachers lack self-regulated work and independent thinking. They waited for me, the pedagogical advisor, to tell them what to do at the beginning of the school year. I kept reminding them of preparing a weekly schedule and following the schedule.

\subsection{Employing Different Techniques, Strategies, and Methods}

The aim of this research was to encourage the students to employ different activities, ways of teaching, and ideas by teaching different classes and grade levels to help them internalize the concept of teaching as a process that includes trial and error. The first attempts of instruction of all the participants were frontal and traditional to some extent. In addition, they were also reluctant to try things more than once. They were either satisfied by their positive experience or unwilling to try again if their experience was not satisfying claiming that the pupils 
didn't cooperate. However, Daboul and Nola showed some willingness later to try techniques that did not work well in their first attempt. Zuzu and Dobi were reminded constantly to follow the steps of Daboul and Nola and the last couple agreed reluctantly to repeat unsatisfying previous attempts.

Varying methods, techniques, and strategies of teaching posed a big challenge to the student teachers. They rejected the idea and felt safe to follow the books and the teacher's guide. The following sentence is quoted from the report of the pedagogical advisor who visited the student teachers in the first intensive practical work week.

One of the issues brought up by the students was how they felt the need to rely heavily on the guidebooks to the textbooks that are used in the classroom. This was discussed by the students themselves who brought peer-and self-criticism concluded that it might be the time-saving to use the guidebook but the teacher's real teaching voice in an original lesson plan is not heard.

The shift highlighted in my observation notes showed that the majority of the students were eager to try different methods and to integrate listening texts, video segments, games, and songs following my constant reminders and frequent calls. Each was required to prepare two games and to exchange them with their classmates in addition to exchanging songs and other texts.

At the beginning, each student teacher was eager to apply activities related to her topic for the seminar paper required in the advanced course of pedagogy. As a result of my repeated calls, they started exchanging materials to help each other implementing different ideas that cover these topics which included cooperative methods, integrating videos in EFL classrooms, and including drama in EFL instruction.

Their attitudes showed a little change over time. For example, in the interviews, Daboul and Zuzu expressed their satisfaction employing different techniques and strategies in their lessons. Dobi and Nola, who concluded that although they have improved their performance a lot by employing different techniques, using games and integrating other innovative ways of teaching, they feel that they need more experience to be fully confident and competent. Salim and Cool didn't improve much in this regard.

These findings are in line with the report provided by the second pedagogical advisor who paid a visit to the school in the second intensive practical work week.

From the lessons observed and the subsequent feedback session, it became clear that although all trainee teachers used a wide variety of teaching techniques and activities in accordance with the demands of the course, they did so to differing degrees of success.

Some trainees demonstrated an intuitive grasp of the added benefit of engaging the students through a variety of activities. Their natural inclination to "have fun while teaching" (quoted) allowed them to contextualize and integrate the activities organically with the learning content and to put them to effective use. Other trainees were less successful in that they incorporated the activities in a mechanical fashion.

\subsection{Showing Resistance to Exposure to Different Settings}

At the beginning of the school year, the student teachers totally rejected the idea of accompanying different English teachers in the school and being exposed to different classes and grade levels. They felt safe to accompany one teacher each and to teach one class only every Wednesday. To meet their needs, I gave them the chance to accompany different teachers and teaching one class only in the first two months. Later, they were required gradually to teach different classes and grade levels.

In the interview, Salim expressed her satisfaction with the fact that she was required to accompany more than one teacher educator in the practical day and observe different lessons and classes. In addition, she was required to teach different classes every week. In the second evaluation she contradicted herself by expressing her dissatisfaction with the requirement of accompanying different teacher trainers and not teaching the same pupils.

\section{Discussion}

The analyzed data show a little change in the pre-service conception of their roles as long-life teachers, which proves that shaping persons' beliefs is a process of different stages. In addition, one year is not sufficient to help EFL trainees make conceptual changes in order to develop professionally, and be more future autonomous in their work. Moreover, it could also be concluded that teacher educators should pay more attention to the influence of the first learning experiences of the student teachers to make the desired change. The subjects inclination to ready-made recipes stems from their previous experiences of learning which are based on control-oriented schooling that encourage transmission of material rather than constructing knowledge and reflecting. Therefore, there is a need to adapt new knowledge and skills about teaching into old cognitive structures and adapt theory into practice to replace prior knowledge and perception (Eilam, 2002). It could be 
achieved by challenging the student teachers' perceptions to their roles as receptive by providing them ample opportunities for practice, inquiry and reflection. They should also be encouraged to take responsibilities for making decisions and not to rely solely on the teacher educator. They should be encouraged to employ multiple-activities, methods and ideas to promote their self-awareness and self-discovery. Challenging the pre-service teachers' perception of teaching should be done consciously by videotaping their lessons frequently and asking guiding questions that help them critically analyze their performances and reflect on them. In addition, written reflections on the effectiveness of the activities, student-teacher interaction, content, classroom management skills should be submitted more frequently to help the student teachers think constantly about different aspects of lessons.

Furthermore, their gradual improvement has been attained in a supportive, and totally non-punitive environment in which they were encouraged to think about their performance and learn from their experiences. However, it could be concluded that they were at their embryonic stage as they were always reminded of varying their methods and employing different techniques and ideas. It could be summarized that some employed different methods and varied their lessons, but they did not necessarily change their concepts.

To achieve the desired change, the practical program in teacher training colleges should be designed for making a conceptual change regarding their roles as student teachers. It means that it should be stated clearly in the rationale of the program. A three-year plan for practicum should be designed including clear criteria for implementing it gradually.

The limitations of this study stem from a local need. It is a self-initiated study and includes a small sample of participants. It emerged as a result of a dire need to make a conceptual change among my student teachers to help them become reflective thinkers and independent in their work by constructing knowledge and being reflective. It should be part of the rationale in teacher education programs for Arabs in Israel and widely implemented.

Since this research is limited in its size and scope, there is a need to conduct a follow-up research to investigate the effect of this attempt on these student teachers for the long run.

\section{References}

Abu Rass, R. (2011). Cultural transfer as an obstacle for writing well in English: The case of Arabic speakers writing in English. English Language Teaching, 4(2), 206-212.

Al-Haj, M. (1999). Higher education among the Arabs in Israel: Situation, needs and recommendations. Haifa, Israel: Univeristy of Haifa, Center for Multiculturalism and Educational Research.

Cochran-Smith, M., \& Lytle, S. (1999). Relationship of knowledge and practice: Teacher learning in communities. Review of Research in Education, 19, 5-28.

Eilam, B. (2002). Passing through a western-democratic teacher education: The case of Israeli Arab Teachers. Teachers College Record, 104(8), 1656-1701. http://dx.doi.org/10.1111/1467-9620.00216

Emmanuel, D. (2005). Role perception of the pedagogical advisor from three points of view: A renewed look at the program for specialization in pedagogical advice. Position Paper 2. Tel Aviv: MOFET (in Hebrew).

Farr, F. (2010). The discourse of teaching practice feedback: A corpus-based investigation of spoken and written modes. London: Routledge.

Hill, L. (2004). Changing minds: Developmental education for conceptual change. Journal of Adult Development, 11(1), 29-40. http://dx.doi.org/10.1023/B:JADE.0000012525.69639.5d

Farrell, T. S. C. (2004). Reflective practice in action: 80 reflection breaks for busy teachers. Thousand Oaks, CA: Crowin.

Ferraro, J. M. (2000). Reflective practice and professional development. Retrieved from http://searcheric.org/digests/ed449120.html

Freeman, D., \& Johnson, K. E. (1998). Reconceptualizing the knowledge-base of language teacher education. TESOL Quarterly, 32(3), 397-417. http://dx.doi.org/10.2307/3588114

Gebhard, J. G., \& Oprandy, R. (1990). Interaction in a teaching practicum. In J. C. Richards \& D. Nunan (Eds.), Second language teacher education (pp. 118-131). New York: Cambridge University Press.

Gebhard, J. G., Gaitan, S., \& Oprandy, R. (1999). Reflecting through a teaching journal. New York: Cambridge University Press. 
Gebhard, J. G., Gaitan, S., \& Oprandy, R. (1990). Beyond prescription: The student teacher as investigator. In J. C. Richards \& D. Nunan (Eds.), Second language teacher education (pp. 16-25). Cambridge: Cambridge University Press.

Gore, J. M., \& Zeichner, K. M. (1991). Action research and reflective teaching in preservice teacher education: A case study from the United States. Teaching and Teacher Education, 7(2), 119-136. http://dx.doi.org/10.1016/0742-051X(91)90022-H

Hill, L. (2004). Changing minds: Developmental education for conceptual change. Journal of Adult Development, 11(1), 29-40. http://dx.doi.org/10.1023/B:JADE.0000012525.69639.5d

Jarvis, P. (2006). The theory of practice of teaching. London: Routledge.

Kegan, D. M. (1992). Professional growth among pre-service and beginning teachers. Review of Educational Research, 62, 129-169.

Kegan, R. (1994). In over our heads: The mental demands of modern life. Cambridge, MA: Harvard University Press.

Mori, R. (2003). Knowledge/personhood dichotomy in TESOL. The Language Teacher, 27(4), 14-15.

Murphey, T. (2000). Becoming contributing professionals: Nonnative-English-speaking teachers in an EFL environment. In K. E. Johnson (Ed.), Teacher education (pp. 105-118). Alexandria, VA: TESOL.

Pajares, M. F. (1992). Teachers' beliefs and educational research: Cleaning up a messy construct. Review of Educational Research, 63(3), 307-333.

Perry, W. (1999). Forms of ethical and intellectual development in the college years: A scheme. San Fransisco: Jossey-Bass. (Original work published 1968).

Resnick, L. B. (1987). Learning in school and out. Educational Researcher, 16, 13-20. http://dx.doi.org/10.2307/1175725

Richards, J. C., \& Farrell, T. S. (2011). Professional development for language teachers: Strategies for teacher learning. Cambridge: Cambridge Language Education.

Richards, J. C. (1998). Beyond training perspectives on language teacher education. Cambridge: Cambridge University Press.

Tillema, H. H. (1997). Promoting conceptual change in learning to teach. Asia-Pacific Journal of Teacher Education, 25(1), 7-16. http://dx.doi.org/10.1080/1359866970250102

Wang, J., \& Odell, S. J. (2002). Mentored learning to teach according to standards-based reform: A critical review. Review of Education Research, 72(3), 481-546. http://dx.doi.org/10.3102/00346543072003481

Zilberstein, M. (2003). Guidelines for specialization curricula in pedagogical guidance. Tel Aviv: MOFET (in Hebrew).

Zahorik, J. A. (1988). The observing-conferencing role of university supervisors. Journal of Teacher Education, 39, 9-16. http://dx.doi.org/10.1177/002248718803900203 